\title{
EVALUASI HUBUNGAN DOSIS RADIASI TERHADAP KERUSAKAN DNA SEL LIMFOSIT DENGAN MENGGUNAKAN TES COMET
}

\author{
Darlina*, Tur Rahardjo dan Mukh. Syaifudin
}

Pusat Teknologi Keselamatan Metrologi dan Radiasi Jln Lebak Bulus Raya No. 49, Jakarta 12070

*Email : mdarlina@batan.go.id

Diterima: 15 -09-2017

Diterima dalam bentuk revisi: 07-02-2018

Disetujui: 22-02-2018

\section{ABSTRAK}

EVALUASI HUBUNGAN DOSIS RADIASI TERHADAP KERUSAKAN DNA SEL LIMFOSIT DENGAN MENGGUNAKAN TES COMET. Kerusakan asam nukleat (DNA) akibat radiasi atau faktor lain dapat mengarah ke efek yang lebih parah seperti sel kanker. Oleh karena itu diperlukan suatu metode deteksi untuk mengetahui besarnya kerusakan tersebut antara lain dengan metode uji komet yang sederhana. Tujuan penelitian ini adalah mengkaji efek radiasi pada sel limfosit akibat radiasi melalui teknik uji komet. Spesimen darah diiradiasi dosis gamma 2-8 Gy kemudian diisolasi limfositnya dengan histopaque. Isolat limfosit diproses uji komet pada slide dalam kondisi alkali dan hasil pencitraan dianalisis dengan software khusus. Hasil menunjukkan bahwa terdapat korelasi positif parameter komet dengan dosis radiasi, semakin besar dosis paparan semakin besar kerusakan DNA. Diantara parameter uji komet, tail DNA memberikan korelasi yang terbaik dengan dosis radiasi. Disimpulkan bahwa uji komet sangat baik digunakan untuk mengetahui kerusakan DNA akibat radiasi.

Kata kunci: kerusakan DNA, radiasi, tes komet, kondisi alkali

\section{ABSTRACT}

EVALUATION OF RADIATION DOSAGE RELATIONSHIP TO DNA CELL DAMAGE USING COMET TEST Nucleic acid (DNA) damage caused by radiation or other factors may lead to more suffering effects such as cancer cells. Therefore it needs a detection method to determine the extent of these damages, one of them is comet test that is a simple method. The Aim of the research was to assess radiation effects on lymphocyte cells caused by radiation using comet test. Blood speciment was irradiated with gamma rays at doses of 2-8 Gy and then lymphocytes were isolated with histopaque. Isolated lymphocyte to proceed comet test in alkali condition and their images were analyzed with special software. Results showed that there is a positive correlation of comet with radiation dose, higher dose caused higher DNA damage. Among parameters of comet test, tail DNA gave the best correlation with dose of radiation. It can be concluded that comet test is a fit method to evaluated radiation induced DNA damage.

Keywords: DNA damage, radiation, comet test, alkali condition

\section{PENDAHULUAN}

Radiasi pengion telah banyak digunakan dalam pengobatan (radioterapi dan radiodiagnosis), industri, dan penelitian selama lebih dari satu abad setelah penemuan sinar- $X$ oleh Roentgen pada tahun 1895 (1). Namun, penggunaan radiasi untuk tujuan terapi maupun lainnya masih menimbulkan kecemasan terhadap efek negatif paparan radiasi. Paparan radiasi dapat menginduksi kerusakan sel dan subselular pada organisme. Radiasi terutama sinar gamma dapat diserap langsung oleh asam deoksribonukleat (DNA), akan 
mengionisasi dua nukleobasa dan gula, menyebabkan kerusakan pada untai tunggal dan ganda DNA (2).

Kerusakan DNA akibat paparan radiasi pengion adalah terjadinya perubahan struktur molekul gula atau basa, pembentukan dimer, putusnya ikatan hidrogen antar basa, hilangnya gula atau basa dan lain sebagainya. Kerusakan yang lebih parah adalah putusnya salah satu untai DNA yang disebut single strand break (SSB) dan putusnya kedua untai DNA pada posisi yang berhadapan, yang disebut double strand breaks (DSB) (3). Radiasi gamma merusak struktur DNA secara langsung, menyebabkan putusnya untai DNA, atau secara tidak langsung menyebabkan pembelahan molekul air menghasilkan spesi oksigen reaktif (ROS). Spesi ROS akan merusak molekul DNA atau putusnya untai DNA secara oksidatif. Kerusakan oksidatif pada DNA menyebabkan kematian sel lebih lanjut dalam bentuk apoptosis atau nekrosis, Perubahan DNA dapat diperiksa di sel limfosit manusia menggunakan teknik sitogenetik (4).

Sel limfosit darah tepi merupakan sel yang paling sensitif terhadap radiasi sehingga mudah mengalami kerusakan pada DNA-nya. Sehingga sel limfosit darah tepi merupakan sel yang paling umum digunakan sebagai biodosimetri. Biodosimetri adalah proses prediksi dosis radiasi pengion yang diterima seseorang berdasarkan perubahan materi biologis dalam tubuh (5).

Analisis sitogenetika termasuk aberasi kromosom (CA) dan mikronukleus (MN) merupakan biodosimetri klasik (6). Pengujian kelainan kromosom pertama kali diperkenalkan oleh Bender dan Gooch merupakan "gold standard" untuk biodosimetri untuk respon awal kecelakaan radiasi dan penilaian dosis definitif (7). Pengujian tersebut memakan waktu relatif lama untuk tujuan mengetahui respon cepat karena membutuhkan waktu 48 jam sampai 72 jam untuk proses kultur limfosit. Oleh karena itu diperlukan suatu metode yang cepat dan sensitif untuk menilai kerusakan DNA yang disebabkan oleh radiasi pengion. Uji komet, juga dikenal sebagai gel elektroforesis-sel tunggal, dapat mendeteksi kerusakan DNA dan kinetika perbaikan pada tingkat sel tunggal, telah banyak digunakan dalam biologi radiasi, toksikologi, onkologi, dan epidemiologi molekuler dalam beberapa tahun terakhir (8). Uji komet adalah teknik mikrodosimetri cepat dan sensitif yang mungkin cocok untuk biomonitoring manusia, terutama dalam kasus-kasus paparan terkait dengan radiasi pengion (9). Penelitian uji komet pada sel limfosit dilakukan sebagai evaluasi awal untuk mengetahui efek radiasi terhadap kerusakan DNA sel. Percobaan terhadap sel limfosit manusia dilakukan secara in vitro.

Perbedaan jumlah DNA yang putus untai gandanya (double-strand DNA breaks) pada sel akibat paparan radiasi perlu dipelajari secara in vitro maupun in vivo sebagai penelitian pertama untuk melihat potensi komet sebagai biodosimetri (10). Penelitian uji komet pada sel limfosit dilakukan sebagai evaluasi awal untuk mengetahui efek radiasi terhadap kerusakan DNA sel. Percobaan dilakukan secara in vitro Kemudian dibuat kurva respon radiasi untuk menentukan respon kerusakan DNA terhadap dosis paparan radiasi. 


\section{TATA KERJA}

\subsection{Pengambilan darah}

Sampel darah diperoleh dari darah tepi dua relawan pria umur 32 dan 52 tahun, tidak merokok, dan tidak terpapar radiasi. Sampel darah diambil sebanyak $15 \mathrm{ml}$. Sampel darah kemudian dibagi kedalam 5 tabung vacutainer (Becton Dickinson, NJ, USA) yang mengandung lithium heparin sebagai antikoagulan, setiap tabung berisi 3 $\mathrm{ml}$ darah.

\subsection{Radiasi sampel}

Sampel darah diiradiasi dengan radiasi gamma pada iradiator IRPASENA di Pusat Aplikasi Isotop dan Radiasi BATAN Jakarta. Sampel diradiasi pada dosis 2, 4, 6, dan 8 Gy pada laju dosis 380 Gy/jam. Semua sampel darah dibawa dalam ice box pada suhu $5^{\circ} \mathrm{C}$.

\subsection{Isolasi sel limfosit.}

Sel limfosit diisolasi dari sampel radiasi paska iradiasi dengan metode sentrifugasi gradien menggunakan histopak 1077. Darah diencerkan dengan PBS bebas $\mathrm{Ca}$ dan $\mathrm{Mg}$ (dPBS) dengan volume yang sama dan ditambahkan $3 \mathrm{ml}$ histopak diatas permukaan darah kemudian disentrifugasi pada 1500 RPM selama 30 menit. Lapisan limfosit yang berada di lapisan tengah diambil kemudian dicuci dengan APBS dan disentrifugasi pada 1000 RPM selama 15 menit, pencucian diulang sebanyak 2 kali. Pelet diresuspensi dengan $1 \mathrm{ml}$ RPMI kemudian viabilitas sel limfosit dihitung dengan tryphan blue dan menggunakan hemositometer. Sekitar $10^{4} \mathrm{sel}$ per $100 \mu \mathrm{l}$ medium diambil dari setiap dosis radiasi.

\subsection{Uji Komet (11)}

Kerusakan DNA setelah radiasi dievaluasi dengan teknik uji komet yang dilakukan di bawah kondisi alkali sesuai dengan metode Singh (11). Sebanyak $10 \mu \mathrm{l}$ sampel limfosit ditambahkan dengan $70 \mu \mathrm{l}$ low melting point agarose (LMP) dari Sigma. Sebanyak $70 \mu \mathrm{l}$ campuran sampel tersebut diteteskan pada gelas preparat yang sudah dilapisi Normal melting Agarose (Sigma). Preparat direndam selama 1 jam pada $4^{\circ} \mathrm{C}$ dalam larutan lisis $(2.5 \mathrm{M} \mathrm{NaCl}, 100 \mathrm{mM}$ Na2EDTA, $10 \mathrm{mM}$ Tris- $\mathrm{HCl}$, diatur hingga $\mathrm{pH} 10$ dengan $\mathrm{NaOH}$ (Sigma)t dan ditambahkan $1 \%$ Triton X-100 (Sigma) dan $10 \%$ dimethyl sulfoxide (Sigma). Setelah sel lisis, kaca preparat diletakan dengan posisi horisontal dalam tangki elektroforesis yang diisi dengan bufer elektroforesis $(300 \mathrm{mM}$ $\mathrm{NaOH} / 1 \mathrm{mM}$ EDTA, pH 13) dan didiamkan selama 20 menit. Kemudian dilakukan proses elektroforesis pada $25 \mathrm{~V}, 300 \mathrm{~mA}$ selama 20 menit. Setelah elektroforesis, sampel dinetralkan dalam larutan netral (PBS, $\mathrm{pH} 7,4$, dilakukan 3 kali, masing masing 5 menit). Sampel difiksasi dengan metanol kemudian diwarnai dengan ethidium bromide $(2 \mathrm{~g} / \mathrm{ml})$. Prosedur isolasi dan uji Komet dilakukan dalam kondisi gelap.

\subsection{Pengamatan dan Analisa}

Sampel yang telah diwarnai kemudian diamati menggunakan mikroskop flouresen Nikon. Komet diamati pada 50 sel dari setiap perlakuan menggunakan digital imaging system. Sel yang bertumpuk tidak dihitung. Citra komet dianalisa secara digital dengan menggunakan CASPLab comet assay software (12). Hubungan respon dosis 
terhadap kerusakan DNA dianalisa menggunakan Koefisien Korelasi Pearson (15).

\section{HASIL DAN PEMBAHASAN}

Limfosit sel darah tepi diketahui sangat sensitif terhadap radiasi. Radiosensitivitas sel limfosit sangat mempengaruhi hasil analisa kerusakan DNA akibat radiasi dengan uji komet. Fragmen DNA yang rusak akan terlepas kemudian bermigrasi menuju kutub muatan positif selama elektroforesis akan membentuk "comef" (13). Pencitraan komet yang menggambarkan profil DNA di seluruh komet ditunjukkan pada Gambar 1.

Panjang migrasi DNA, yang biasa disebut sebagai panjang ekor jika diukur dari pusat kepala atau ujung kepala ke ujung ekor atau panjang gambar (panjang seluruh komet) merupakan parameter pertama dari hasil pengukuran hasil komet yang digunakan untuk mengukur kerusakan DNA. Berdasarkan profil DNA dari hasil pencitraan uji komet maka parameter yang umum digunakan dalam mengukur kerusakan DNA adalah (a) Panjang ekor komet (tail length), (b) DNA ekor komet (tail DNA), (c) Momen ekor komet (tail moment), (d) Momen ekor olive oil (olive tail moment) (13).

Pengujian kerusakan DNA sel limfosit akibat paparan radiasi sinar gamma dengan menggunakan uji komet alkali. Sel limfosit darah perifer diradiasi dengan dosis radiasi bertingkat. Pada penelitian ini sel limfosit diperoleh dari sampel darah dua donor pria dengan usia 32 tahun dan 52 tahun, tidak merokok dan tidak terpapar radiasi. Sampel darah diradiasi dengan sinar gamma dari sumber Cobalt 60, dengan dosis 2, 4, 6, dan 8 Gy.

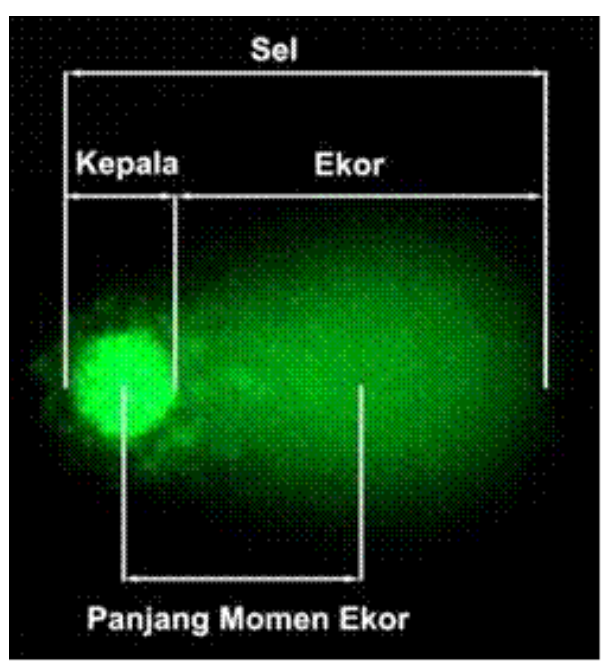

Gambar 1. Profil DNA dari hasil pencitraan Komet

(14)

Kerusakan DNA dihubungkan dengan beberapa parameter hasil pengukuran komet tersebut di atas. Pengukuran komet yang terhandal jika mencerminkan tingkat kerusakan DNA yang disebabkan perpindahan enerji secara linier. Kerusakan DNA yang dihasilkan berbanding lurus dengan dosis radiasi, setiap perubahan dosis radiasi harus tercermin secara proporsional mengubah dalam pengukuran komet.

Dari hasil pengukuran komet sel limfosit setelah terpapar radiasi dengan beberapa dosis, diperoleh nilai panjang ekor komet ( $T L$ ), DNA ekor komet (tail DNA), momen ekor komet ( $T M)$, momen ekor olive oil (olive tail moment) yang dihitung dengan software CAPSLab (Tabel 1). Nilai rerata kedua sampel digunakan untuk menganalisa hubungan respon dosis yang ditampilkan pada Gambar 2. 
Tabel 1. Nilai rerata TL, tail DNA, TM , dan OTM dari uji komet pada sel limfosit yang diiradiasi dosis 0,2 , 4,6 , dan 8 Gy

\begin{tabular}{ccccccccc}
\hline \multirow{2}{*}{$\begin{array}{c}\text { Dosis } \\
\text { (Gy) }\end{array}$} & \multicolumn{2}{c}{ Nilai TL } & \multicolumn{2}{c}{ Nilai tail DNA } & \multicolumn{2}{c}{ Nilai TM } & \multicolumn{2}{c}{ Nilai OTM } \\
\cline { 2 - 9 } & A & B & A & B & A & B & A & B \\
\hline $\mathbf{0}$ & $4,4 \pm 2,00$ & $3,9 \pm 1,00$ & $0,7 \pm 0,10$ & $0,3 \pm 0,10$ & $0,05 \pm 0,00$ & $0,03 \pm 0,01$ & $0,2 \pm 0,02$ & $0,13 \pm 0,03$ \\
$\mathbf{2}$ & $6,6 \pm 2,10$ & $5,7 \pm 2,10$ & $1,2 \pm 0,20$ & $2,3 \pm 0,20$ & $0,15 \pm 0,00$ & $0,24 \pm 0,03$ & $0,4 \pm 0,04$ & $0,8 \pm 0,08$ \\
$\mathbf{4}$ & $6,6 \pm 1,80$ & $10,2 \pm 3,00$ & $3,6 \pm 1,80$ & $6,6 \pm 2,00$ & $0,3 \pm 0,00$ & $0,9 \pm 0,03$ & $0,8 \pm 0,05$ & $1,8 \pm 0,09$ \\
$\mathbf{6}$ & $36,6 \pm 9,00$ & $36,5 \pm 9,00$ & $9,8 \pm 4,00$ & $9,4 \pm 3,00$ & $4 \pm 2,00$ & $3,6 \pm 2,00$ & $4,2 \pm 2,20$ & $4 \pm 1,50$ \\
$\mathbf{8}$ & $51,4 \pm 10,0$ & $52 \pm 11,00$ & $22 \pm 9,00$ & $18,9 \pm 7,00$ & $14 \pm 1,90$ & $10,6 \pm 3,00$ & $8,9 \pm 3.00$ & $9,6 \pm 1,00$ \\
\hline
\end{tabular}

Keterangan: $A=$ Sampel 1

$\mathrm{B}=$ Sampel 2
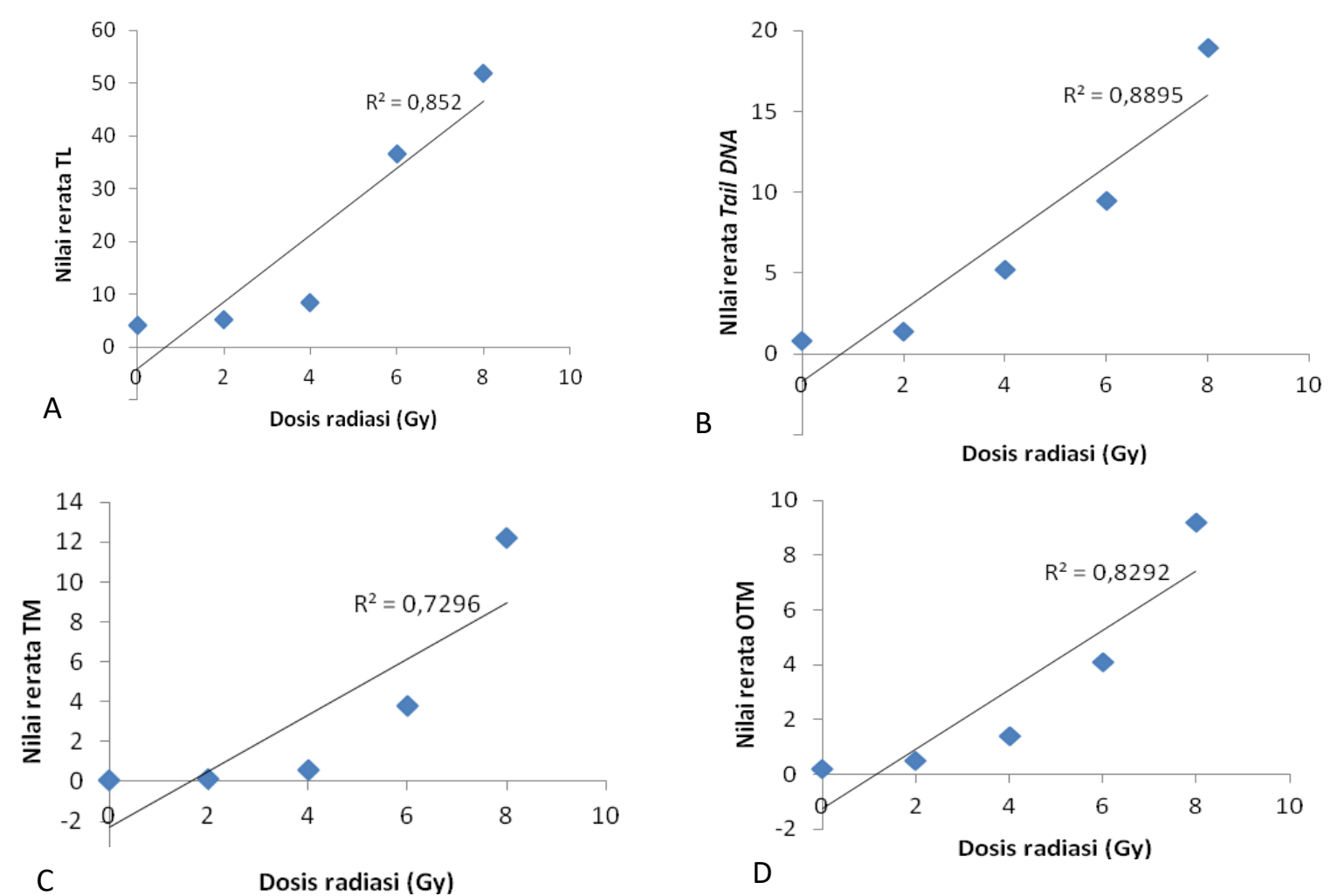

Gambar 2. Kurva nilai TL (A), tail DNA (B), TM (C), dan OTM (D) dari uji komet pada sel limfosit yang diiradiasi dosis 2, 4, 6, dan 8 Gy

Kerusakan DNA diakibatkan paparan radiasi ditunjukkan oleh kurva indikator parameter TL, tail DNA, TM, dan OTM (Gambar 2). Berdasarkan kurva korelasi respon sel limfosit terhadap dosis radiasi pada keempat parameter komet, memberikan bentuk korelasi linear positif.
Hal ini menunjukkan semakin besar dosis paparan semakin besar nilai parameter kerusakan DNA dengan uji komet.

Dari analisa regresi diperoleh nilai koefisien korelasi kuadrat atau koefisien determinasi $\left(\mathrm{R}^{2}\right)$ dari slope kurva parameter $\mathrm{TL}$, tail DNA, TM, dan OTM. Kekuatan 
hubungan respon radiasi terhadap parameter komet ditunjukkan dari nilai koefisien korelasi $(\mathrm{R})$ yang merupakan akar koefisien determinasi (VR2). Hasil pengukuran komet diperoleh rentang nilai dari yang tertinggi adalah $\mathrm{R}$ kurva tail $D N A$ 0,943, kurva TL 0,921, kurva OTM 0,911, dan kurva TM 0,854. Berdasarkan dari nilai $\mathrm{R}$ keempat parameter memberikan kriteria korelasi kuat sehingga dapat menjadi indikator yang baik untuk kerusakan DNA akibat radiasi. Diantara ke-4 parameter tersebut tail DNA memberikan korelasi yang terbaik dengan dosis radiasi. Tail DNA merupakan indikator terbaik untuk melihat kerusakan DNA akibat radiasi. Koefisien korelasi tail $D N A$ yang tertinggi $(\mathrm{R}=0,943)$ menunjukkan sensitivitas tail DNA lebih baik dan lebih responsif dibandingkan dengan parameter komet yang lain ( $\mathrm{R}$ pada kurva $\mathrm{TL}=0,921$, OTM $=0,911$, dan $\mathrm{TM}=0,854$ )

Persentase DNA ekor merupakan parameter yang sangat disarankan dalam menganalisis citra komet. Hal tersebut dikarenakan \% T dapat diekspresikan dalam skala nominal mulai dari 0 hingga $100 \%$. Dengan demikian dapat dilakukan komparasi antara hasil penelitian yang menggunakan tes komet (9). Kumaravel dkk. melakukan penelitian serupa dengan menggunakan sel limfosit manusia yang diradiasi dengan sinar gamma dengan rentang dosis radiasi 0-8 Gy. Hasil pencitraan komet diukur dengan software Komet 5.0 (16). Komet yang didapat akibat radiasi dikorelasikan dengan dosis kurva regresi. Koefisen korelasi (R) yang dihasilkan setiap parameter diatas 0,9 menunjukkan indikator yang baik. Koefisien korelasi yang terbaik pada parameter tail $D N A$ diatas 0,9 , diketahui adanya hubungan yang sangat baik antara dosis-respon dengan kerusakan DNA pada lingkup dosis ini $(9,16)$. Persentase DNA ekor merupakan parameter yang sangat disarankan dalam menganalisis citra komet. Hal tersebut dikarenakan \%T dapat diekspresikan dalam skala nominal mulai dari 0 hingga $100 \%$. Dengan demikian komparasi antara hasil penelitian yang menggunakan tes komet dapat dilakukan.

Wang Y. dkk. (10) melakukan penelitian pada limfosit mencit yang diberi paparan radiasi secara in vitro dan in vivo dan kerusakan DNA DSBs limfosit ditentukan dengan uji komet. Hasil penelitian menunjukkan tidak ada perbedaan yang signifikan pada kedua kelompok tersebut. Dengan demikian kurva respon dosis pada paparan radiasi in vitro dapat menggambarkan kerusakan DNA setelah paparan radiasi in vivo.

Teknik uji komet yang cepat dan sederhana ini terbukti dapat dipergunakan untuk berbagai tujuan seperti mengetahui mutagenitas agensia lingkungan termasuk radiasi pengion meliputi DNA double strand break, crosslink, kerusakan basa dan apoptosis. Genotoksisitas radiasi untuk tujuan radioterapi juga dapat diuji dengan teknik yang memiliki prinsip bahwa sel dengan bertambahnya frekuensi DSB dari DNA akan menunjukkan bertambahnya laju migrasi DNA ke arah anoda dalam suatu sistem elektroforesis (17). Molekul DNA mengandung gugus fosfat bermuatan listrik negatif saat berada pada larutan alkali, sehingga daerah pada untai ganda DNA 
yang mengalami pengenduran dan mengandung DSB akan bermigrasi menuju kutub positif (anoda) saat elektroforesis. Migrasi tersebut akan membentuk ekor komet, sedangkan daerah yang tidak mengalami pengenduran akan membentuk kepala komet (18).

\section{KESIMPULAN}

Berdasarkan kurva korelasi respon sel limfosit terhadap dosis radiasi pada keempat parameter komet, memberikan bentuk korelasi linear positif. Hal ini menunjukkan semakin besar dosis paparan semakin besar nilai parameter kerusakan DNA dengan uji komet. Berdasarkan koefisien korelasi, keempat parameter memberikan kriteria korelasi kuat sehingga dapat menjadi indikator yang baik untuk kerusakan DNA akibat radiasi. Diantara keempat parameter, tail DNA memberikan korelasi yang terbaik dengan dosis radiasi. Tail DNA merupakan indikator terbaik untuk melihat kerusakan DNA akibat radiasi.

\section{UCAPAN TERIMA KASIH}

Terima kasih diucapkan kepada Pimpinan PTKMR BATAN yang telah memberikan dana DIPA tahunan sehingga penelitian ini dapat selesai.

\section{DAFTAR PUSTAKA}

1. Timmins Jk. Communication of benefits and risks of medical radiation : a historical perspective . Helath Phys. 2011;101(5):562-5.

2. Zhang Y, Guo J, Qi Y, Shao Q, Liang J. ScienceDirect The prevention of radiation-induced DNA damage and apoptosis in human intestinal epithelial cells by salvianic acid A. J Radiat Res Appl Sci . 2014;7(3):27485.

3. IAEA. Cytogenetic Dosimetry: Applications in Preparedness for and Response to Radiation Emergencies. 1st ed. IAEA, editor. Vienna; 2011: 327.

4. Cardis E, Howe G. Health Effects Due to Radiation from the Chernobyl Accident . Annex D of UNSCEAR 2008 : Sources and Effects of lonizing Radiation . Volume 2 : Effects Book review. J Radiol Prot. 2011;31:275-7.

5. Nandhakumar S, Parasuraman S, Shanmugam MM, K RR, Chand $P, B$ VB. Evaluation of DNA damage using single-cell gel electrophoresis ( Comet Assay ). J Pharmacol Pharmacoterapeutics. 2011;2(2):107-11.

6. Rana S, Raj K.,Sarwat Sulatana RK. Radiation-Induced Biomarkers for Detection and Assesment of Absorbed Radiation Doses. J Pharm Bioallied Sci. 2010;2(3):189-96.

7. Voisin P. Mutation Research /

Genetic Toxicology and

Environmental Mutagenesis

Standards in biological dosimetry : A requirement to perform an appropriate dose assessment. Mutat Res - Genet Toxicol Environ Mutagen . 2015;793:115-22.

8. Seidel C, Lautenschläger C, Dunst J, Müller A-C. Factors influencing heterogeneity of radiation-induced 
DNA-damage measured by the alkaline comet assay. Radiat Oncol . 2012;7(1):61.

9. Güerci a, Zúñiga L, Marcos R. Construction and validation of a dose-response curve using the comet assay to determine human radiosensitivity to ionizing radiation. $\mathrm{J}$ Toxicol Environ Health A. 2011;74(15-16):1087-93.

10. Wang Y, Xu C, Du LQ, Cao J, Liu JX, Su $X$, et al. Evaluation of the comet assay for assessing the doseresponse relationship of DNA damage induced by ionizing radiation. Int J Mol Sci. 2013;14(11):22449-61.

11. Dusinska M, Collins AR. The comet assay in human biomonitoring: Geneenvironment interactions.

Mutagenesis. 2008;23(3):191-205.

12. González JE, Romero I, Barquinero JF, García O. Automatic analysis of silver-stained comets by CellProfiler software. Mutat Res / Genet Toxicol Environ Mutagen. 2012;748(4113):60-4.

13. Ar C, Azqueta A. DNA repair as a biomarker in human biomonitoring studies ; further applications of the comet assay . Mutat Res. 2012;736:122-9.

14. Ramadhani, Dwi, Devita T. dan VA. Optimalisasi Tes Komet Untuk Penentuan Tingkat Kerusakan DNA Akibat Paparan Radiasi Pengion. J Sains dan Teknol Nukl Indones. 2016;17(1):37-48.

15. Ersson $C$, Möller L. The effects on DNA migration of altering parameters in the comet assay protocol such as agarose density, electrophoresis conditions and durations of the enzyme or the alkaline treatments. Mutagenesis. 2011;26(6):689-95.

16. Kumaravel TS, Jha AN. Reliable Comet assay measurements for detecting DNA damage induced by ionising radiation and chemicals. Mutat Res. 2006;605:7-16.

17. Shcherbatyuk T.G.. A New Version of Comet assay. CTM J. 2016;8(1):206.

18. Mikloš M, Gajski G, Garaj-Vrhovac V. Usage of the standard and modified comet assay in assessment of DNA damage in human lymphocytes after exposure to ionizing radiation. Radiol Oncol. 2009;43(2):97-107. 